\title{
The susceptibility of S-layer-positive and S-layer-negative Aeromonas strains to complement-mediated lysis
}

\author{
J. Michael Janda, Robert P. Kokka† and Linda S. Guthertz
}

Author for correspondence: J. Michael Janda. Tel: +1 510540 2242. Fax : +1 5105402374.

Microbial Diseases

Laboratory, Division of Communicable Disease Control, California Department of Health Services, Berkeley, CA 947041011, USA

\begin{abstract}
Forty strains of Aeromonas hydrophila and Aeromonas veronii recovered from invasive and non-invasive infections were tested for their susceptibility to complement-mediated lysis by $65 \%$ pooled human serum (PHS). Based upon the results of this assay, two major populations could be defined. The first group $(n=20)$ consisted of serogroup 0:11 strains, all of which possessed a paracrystalline surface layer (5 layer); all of these strains were refractory to the bactericidal activity of $65 \%$ PHS with the exception of A. hydrophila strain AH-121, which was composed of mixed subpopulations of serum-susceptible and serum-resistant clones. A second collection of isolates $(n=20)$, all of which were S-layer-negative, contained a subgroup of strains $(n=7)$ that were highly susceptible to complement-mediated lysis, showing a greater than 100 -fold reduction of viable progeny within 30 min of exposure to $65 \%$ PHS. Serumresistant strains from both groups could not be lysed by exposure of bacterial cells to polyclonal somatic or whole cell antisera or to $30 \mu \mathrm{g} \mathrm{ml}^{-1}$ of polymyxin B nonapeptide prior to challenge with $65 \%$ PHS. Analysis of selected serumresistant and serum-susceptible strains from both groups showed that all isolates activated the complement pathway and most bound $\mathrm{C3b}$ to the cell surface, indicating that the inability of complement to lyse serum-resistant strains was related to a defect in the terminal portions of the complement pathway. The major differences noticed between serum-resistant and serumsusceptible strains were a lack of a definable lipopolysaccharide side chain profile and higher $\mathbf{5 0} \%$ lethal dose values in strains that were susceptible to complement-mediated lysis.
\end{abstract}

Keywords: Aeromonas, S layers, serum resistance, pathogenicity

\section{INTRODUCTION}

One of the most intriguing appendages on the outer surface of many Gram-negative and Gram-positive bacteria is the $S$ layer, or paracrystalline surface layer (Messner $\&$ Sleytr, 1992). While the majority of recently described Slayers have been associated with saprophytic bacteria, an increasing number of human and animal pathogens have also been reported to contain such structures. Pathogenic bacteria having such S layers include Clostridium botulinum, Aeromonas salmonicida, Campylobacter fetus subsp. fetus,

†Present address: Chiron Corporation, 4560 Horton Street, Emeryville, CA 94608-2916, USA.

Abbreviations: PHS, pooled human serum; PMBN, polymyxin B nonapeptide; S-layer, paracrystalline surface layer; SAP, surface array protein.
Mycobacterium bovis and Campylobacter (Wolinella) recta (Messner \& Sleytr, 1992; Kobayashi et al., 1993).

Very little information is presently available on the role(s) $\mathrm{S}$ layers may play in microbial pathogenesis. Several functions for these layers have been proposed or alluded to and include action as a barrier or molecular sieve, and involvement in adhesive (attachment) activities or in resistance to normal immune functions such as complement-mediated lysis or phagocytosis by professional or non-professional phagocytes (Messner \& Sleytr, 1992). Munn et al. (1982) assessed the bactericidal activity of normal and immune fish sera against $A$. salmonicida and found that the $\mathrm{S}$ layer in conjunction with lipopolysaccharide (LPS) played an integral part in the overt resistance of the bacterium to complement-mediated lysis. In similar studies performed with Camp. fetus, 
Table 1. Characteristics of Aeromonas strains used in this study

\begin{tabular}{|c|c|c|c|}
\hline Defining character & Genomospecies & Source & Strain(s) \\
\hline \multirow{9}{*}{$\begin{array}{l}\text { Serogroup O: } 11 ; \\
\text { S layer-positive* }\end{array}$} & A. bydrophila & Blood & $\mathrm{AH}-342$ \\
\hline & & Wound & AH-121, AH-357 \\
\hline & & Faeces & AH-205, AH-321, AH-332 \\
\hline & & Animals & LL1, AH-252 \\
\hline & & Water & NMRI-54 \\
\hline & A. veronii biotype & Blood & AS-39, AS-76, AS-86, AS-114, AS- 180 \\
\hline & sobria & Wound & AS-143, AS-151, AS-218 \\
\hline & & Faeces & AS-28 \\
\hline & & Animals & ATCC 9071, AS-174 \\
\hline \multirow[t]{8}{*}{$\begin{array}{l}\text { Serogroup non-O: } 11 ; \\
\text { S layer-negative* }\end{array}$} & A. bydrophila & Blood & $\begin{array}{l}\text { AH- } 88, \text { AH-106, AH-145, AH-184, } \\
\text { AH-186, AH-211, AH-351, AH-360, } \\
\text { AH-361 }\end{array}$ \\
\hline & & Wound & NMRI-7, AH-178 \\
\hline & & Faeces & AH-208, AH-319 \\
\hline & & Urine & AH-78 \\
\hline & A. veronii biotype & Blood & AS -127, AS -315 \\
\hline & sobria & Faeces & AS -320 \\
\hline & & Unknown & AS-53 \\
\hline & A. bydrophila complex & Animals & NCMB 1134, ATCC 14715 \\
\hline
\end{tabular}

* As determined by transmission electron microscopy (thin section).

isogenic mutants lacking the $100 \mathrm{kDa}$ surface array protein (SAP) which forms the $S$ layer were found to be serum-susceptible, unlike their parental counterparts (Blaser et al., 1987).

Recently, several other species within the genus Aeromonas have been found to possess S layers (Paula et al., 1988; Kokka et al., 1991a). Strains of these species (A. bydrophila, $A$. veronii biotype sobria) possessing S layers cause diseases in humans and animals (particularly fish) and are often associated with invasive systemic infections (septicaemia, peritonitis) in these vertebrates. Since resistance to complement-mediated lysis is thought to play an important role in disseminated disease caused by Gramnegative bacteria (Figueroa \& Densen, 1991), and in light of the remarkable similarities in surface characteristics and disease spectrum of SAP-positive Camp. fetus, $A$. bydrophila and $A$. veronii, we have investigated whether or not the $\mathrm{S}$ layer of the latter two species is responsible for serum resistance in a fashion analogous to that previously determined for $\mathrm{S}$ layer-positive Camp. fetus and $A$. salmonicida.

\section{METHODS}

Organisms. Forty mesophilic strains of $A$. bydropbila or $A$. veronii were investigated (Table 1 ). These strains were identified biochemically to genomospecies using a recently described scheme of phenotypic tests (Abbott et al., 1992). Strains were further subdivided into two groups based upon their reactivity against $\mathrm{O}: 11$ antisera in slide agglutination assays (Kokka \& Janda, 1990). All O:11 strains were autoagglutination-positive $\left(\mathrm{AA}^{+}\right)$and possessed an $\mathrm{S}$ layer as determined by thin-section transmission electron microscopy (Kokka et al., 1991a). The remaining 20 strains were S-layer-negative and displayed diverse phenotypes and were designated non-O:11 strains; some of these non-O:11 strains were subsequently serogrouped through the courtesy of T. Shimada (National Institutes of Health, Tokyo, Japan).

Serum susceptibility studies. The susceptibility of all 40 Aeromonas strains to complement-mediated lysis by $65 \%$ pooled human serum (PHS) was determined by microassay as previously described (Paula et al., 1988). Briefly, exponential-phase bacteria $\left(6 \times 10^{6}-3 \times 10^{7}\right.$ c.f.u. $)$ suspended in phosphatebuffered saline (PBS, pH 7.2) were mixed with $65 \%(\mathrm{v} / \mathrm{v})$ PHS in microfuge tubes and incubated for $120 \mathrm{~min}$ at $35^{\circ} \mathrm{C}$. Susceptibility or resistance to PHS was determined at $120 \mathrm{~min}$ by the criteria of Taylor (1983) after determining the number of surviving bacteria (c.f.u. $\mathrm{ml}^{-1}$ ) when compared to initial inoculum $(t=0)$.

Some isolates were additionally challenged against PHS after presensitization $\left(25^{\circ} \mathrm{C}, 30 \mathrm{~min}\right)$ with a 1:32 dilution of polyclonal antisera (rabbit, complement-inactivated) raised against whole cell (WC) or somatic (O) antigen preparations of the homologous strain. The effect of polymyxin $B$ nonapeptide (PMBN, Boehringer Mannheim) on the serum susceptibility status of some strains was determined by the simultaneous incubation of the challenge inoculum with $65 \%$ PHS and $30 \mu \mathrm{g}$ PMBN (Viljanen et al., 1986).

For several strains (AH-78, AS-178, AH-121), surviving bacteria from a single exposure (cycle) to $65 \%$ PHS were centrifuged, rechallenged with fresh $65 \%$ PHS, and reincubated for an additional $120 \mathrm{~min}$. Surviving colonies (clones) from single $(120 \mathrm{~min})$ or double $(240 \mathrm{~min})$ exposures to $65 \%$ PHS were picked and regrown in brain heart infusion broth (BHIB). These cultures were then rechallenged as above with one or two 
independent exposures (cycles) to fresh $65 \%$ PHS. Percentage survival was determined by plate count relative to the initial challenge inoculum. Parental wild-type clones (clone 1) which had never been exposed to PHS were included as controls.

Complement activation. The ability of selected Aeromonas strains to activate the complement pathway was determined by the reduction in $\mathrm{CH}-50$ units when compared to controls (Tamplin et al., 1983). Assays were performed in microtitre plates using a high titre $\mathrm{CH}-50$ standard containing $244 \mathrm{U} \mathrm{ml}^{-1}$ (Sigma). Exponential-phase bacteria $\left(5 \times 10^{6}-3 \times 10^{7}\right)$ contained in $35 \mu \mathrm{l}$ were mixed with $65 \mu \mathrm{l}$ of the reference complement sera for $2 \mathrm{~h}$ at $35^{\circ} \mathrm{C}$. Complement activation was defined for each strain as 100 minus the percentage of the control $\mathrm{CH}-50$ remaining in each sample.

C3b binding. Aeromonas strains were grown in BHIB for $18-20 \mathrm{~h}$ at $35^{\circ} \mathrm{C}$ and after overnight incubation were diluted into fresh BHIB and reincubated for an additional $2-4 \mathrm{~h}$ at $35^{\circ} \mathrm{C}$ to obtain exponential-phase bacteria. Such cultures were then harvested, centrifuged, and resuspended in PBS ( $\mathrm{pH} 7.4)$ and spectrophotometrically $\left(\mathrm{OD}_{610}\right)$ adjusted to approximately $5 \times 10^{6}$ to $1 \times 10^{7}$ c.f.u. $\mathrm{ml}^{-1}$; cells were then pelleted in a Beckman Microfuge $\mathrm{E}$ and the supernatant was discarded. Exponential-phase cells were then resuspended in $300 \mu \mathrm{l}$ of $30 \%$ fresh serum (in PBS) and incubated for $30 \mathrm{~min}$ at $37^{\circ} \mathrm{C}$ (Horwitz \& Silverstein, 1980; Aguero et al., 1984). Following incubation, $1 \mathrm{ml}$ cold $10 \mathrm{mM}$ EDTA in PBS was added. Cells were then centrifuged and washed once in PBS before incubation for $15 \mathrm{~min}$ in $100 \mu \mathrm{l}$ of a $1: 10$ dilution of FITC-conjugated goat anti-human C3 IgG (Jackson). Following incubation with conjugate, cells were washed once and resuspended in $100 \mu \mathrm{l}$ PBS. C3 coating of bacteria was determined by placing a $25 \mu \mathrm{l}$ portion of this suspension on a slide with a cover slip and then examining cells for fluorescence using an epifluorescence microscope (Horwitz \& Silverstein, 1980; Aguero et al., 1984).

Lipopolysaccharide (LPS) analysis. The LPS content of selected Aeromonas strains was evaluated by SDS-PAGE of boiled, proteinase-K-treated whole-cell suspensions followed by silver staining (Kokka et al., 1990). Chemotypes resulting from such analysis were designated as follows: type $A$, homogeneous $O$ polysaccharide side chain profile; type $B$, heterogeneous $O$ polysaccharide side chain profile; type $\mathrm{C}, \mathrm{O}$ side chain deficient or not detectable.

Mouse pathogenicity. The relative pathogenicity of selected aeromonads was determined by LD-50 studies performed in outbred Swiss-Webster mice (Janda \& Kokka, 1991). Sets of five mice were challenged intraperitoneally with concentrations of the respective strain ranging between $10^{5}$ and $10^{9}$ c.f.u. Mice were observed daily for 1 week. All mice succumbing to Aeromonas infection died within $72 \mathrm{~h}$ of inoculation; LD-50 values for each strain were then calculated according to the method of Reed \& Muench (1938).

\section{RESULTS}

\section{Serum susceptibility}

We initially characterized 40 Aeromonas strains for their susceptibility to complement-mediated lysis in microassays using $65 \%$ PHS (Fig. 1). Of the 40 strains tested, 30 $(75 \%)$ were resistant to inactivation by PHS, exhibiting a 2-13-fold increase in c.f.u. over the $2 \mathrm{~h}$ incubation period. When strains were further subdivided according to whether or not they belonged to serogroup $O: 11$, a striking difference was noted. For serogroup $\mathrm{O}: 11$ strains,
$95 \%(19 / 20)$ were resistant to complement-mediated lysis, the only exception being one $A$. bydrophila strain (AH-121) whose numbers decreased fivefold during the incubation period. For non-O:11 strains, 45\% (9/20) were found to be susceptible to complement-mediated lysis, with most of these serum-susceptible strains $(88 \%$, $8 / 9$ ) showing a 100 -fold (two logs) or greater decrease in viable bacteria over the course of the incubation with PHS.

To study the inactivation of serum-susceptible strains by complement, an $A$. bydropbila isolate (designated AH-78) from urine was chosen for further study. In time-course experiments using an LPS mutant (Salmonella typhimurium TV $119 \mathrm{Ra}$ ) as a positive control, rapid loss of cell viability in strain AH-78 could be seen within $30 \mathrm{~min}$ of coincubation with $65 \%$ PHS with $<1 \%$ of the initial inoculum recoverable by direct plate counts; this dramatic inactivation was greater than that seen in concurrent inactivation studies performed with S. typhimurium TV $119 \mathrm{Ra}$ (Fig. 2). After $60 \mathrm{~min}$ incubation no viable bacteria could be detected in either sample. When PHS was preincubated for $30 \mathrm{~min}$ at $56^{\circ} \mathrm{C}$ to inactivate complement, both strains showed large increases in c.f.u. within $2 \mathrm{~h}$ of incubation at $35^{\circ} \mathrm{C}$.

\section{Exposure to polyclonal antisera}

To see whether immune sera raised in rabbits against either whole-cell or somatic antigen preparations could activate the lytic response, two strains, $A$. veronii biotype sobria ATCC 9071 and $A$. bydrophila NMRI-54, were challenged in microassays against rabbit immune sera to either antigenic preparation. As can be seen in Table 2,

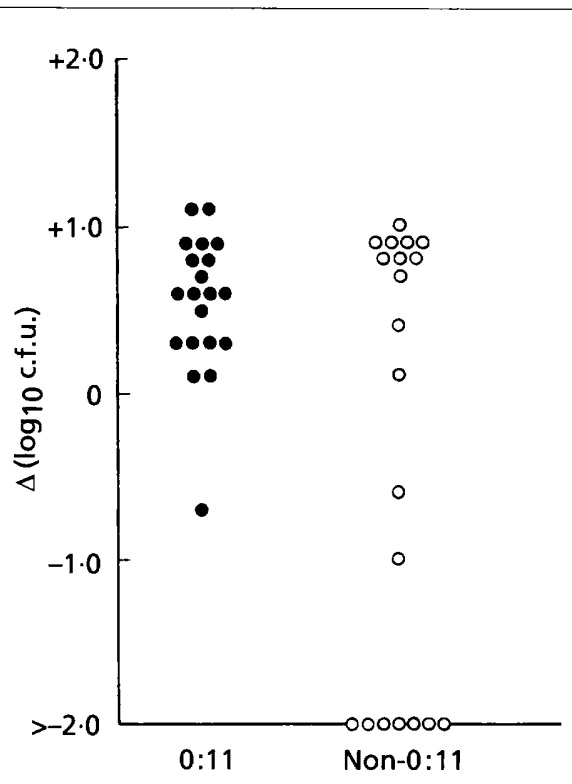

Fig. 1. Susceptibility of 40 Aeromonas strains to complementmediated lysis in the presence of $65 \%$ PHS (0, serogroup 0:11, $n=20$; 0 , serogroup non-O:11, $n=20$ ). Change in c.f.u. represents data points obtained at $120 \mathrm{~min}$. 
Table 2. Effect of various treatments on the susceptibility of $0: 11$ Aeromonas to lysis

\begin{tabular}{|lllc|}
\hline $\begin{array}{l}\text { Challenge } \\
\text { strain }\end{array}$ & Pretreatment* & $\begin{array}{l}\text { Serum } \\
\text { source }\end{array}$ & $\begin{array}{c}\text { Susceptibility } \\
(\Delta \text { c.f.u. })\end{array}$ \\
\hline A. veronii & None & PHS & $+0 \cdot 7$ \\
ATCC 9071 & None & RIS(O) & $+1 \cdot 0$ \\
& None & RIS(WC) & $+0 \cdot 1$ \\
& RIS(O) & PHS & $+0 \cdot 6$ \\
& RIS(WC) & PHS & +0.5 \\
A. bydropbila & None & PHS & $+0 \cdot 3$ \\
NMRI-54 & None & RIS(O) & $+0 \cdot 3$ \\
& None & RIS(WC) & $+0 \cdot 8$ \\
& RIS(O) & PHS & +0.6 \\
& RIS(WC) & PHS & $+0 \cdot 2$ \\
\hline
\end{tabular}

* Preincubation of indicated strain with a $1: 32$ dilution of the indicated antiserum (complement-inactivated) prior to PHS challenge. RIS, rabbit immune serum against somatic $(\mathrm{O})$ or whole-cell (WC) antigens of the homologous strain.

† Change in viable progeny $\left(\log _{10}\right.$ c.f.u. $)$ at $120 \mathrm{~min}$ of incubation when compared to $t=0$.

neither strain was inactivated in the presence of whole-cell or somatic antiserum; the same held true when each strain was preincubated with a $1: 32$ dilution of antiserum prior to challenge with normal $65 \%$ PHS.

\section{Effect of PMBN}

PMBN is a nine-amino-acid cationic peptide that is a derivative of polymyxin B (Viljanen et al., 1986). It has previously been shown to enhance the bactericidal activity

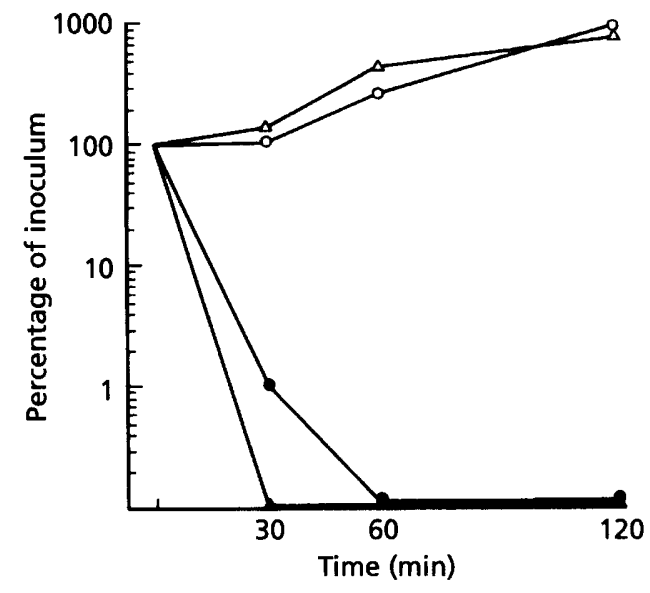

Fig. 2. Kinetics of growth of $A$. hydrophila $A H-78$ in the presence of normal $(\Delta)$ and complement-inactivated $(\triangle) 65 \%$ PHS. For comparison, growth of the Ra mutant $S$. typhimurium TV 119 in normal (O) and complement-inactivated $(O)$ serum $\left(56^{\circ} \mathrm{C}, 30 \mathrm{~min}\right)$ is also shown.

of complement in several Gram-negative species including Salmonella and Escherichia (Viljanen et al., 1986). We therefore challenged several serum-resistant, O:11, Slayer-positive Aeromonas strains with PHS in the presence of PMBN (Table 3). Of the four O:11 strains challenged, only one (strain AS-28) showed a quantitative decrease in c.f.u. when incubated in the presence of $30 \mu \mathrm{g} P M B N$ and $65 \%$ PHS ; this decrease amounted to a 63 -fold reduction in c.f.u. When strain AS-28 was incubated in the presence of PMBN and $65 \%$ PHS (complement-inactivated), lytic activity was destroyed, indicating that lysis was the result of complement and not the PMBN itself.

Table 3. Effect of PMBN on the susceptibility of Aeromonas to pooled human serum

\begin{tabular}{|c|c|c|c|c|c|}
\hline Organism & Serogroup & PHS* & PHS(CI) $\dagger$ & PMBN $\ddagger$ & $\Delta$ C.f.u. $\S$ \\
\hline A. bydropbila NMRI-54 & $0: 11$ & $\begin{array}{l}+ \\
+\end{array}$ & $\begin{array}{l}- \\
-\end{array}$ & $\begin{array}{l}- \\
+\end{array}$ & $\begin{array}{l}+1 \cdot 3 \\
+0 \cdot 9\end{array}$ \\
\hline A. bydropbila LL1 & $\mathrm{O}: 11$ & $\begin{array}{l}+ \\
+\end{array}$ & $\begin{array}{l}- \\
-\end{array}$ & $\begin{array}{l}- \\
+\end{array}$ & $\begin{array}{l}+0.6 \\
+0.9\end{array}$ \\
\hline A. veronii AS-76 & O:11 & $\begin{array}{l}+ \\
+\end{array}$ & $\begin{array}{l}- \\
-\end{array}$ & $\begin{array}{l}- \\
+\end{array}$ & $\begin{array}{l}+0.5 \\
+0.1\end{array}$ \\
\hline A. veronii AS- 28 & O:11 & $\begin{array}{l}+ \\
+ \\
-\end{array}$ & $\begin{array}{l}- \\
- \\
+\end{array}$ & $\begin{array}{l}- \\
+ \\
+\end{array}$ & $\begin{array}{l}+1 \cdot 1 \\
-0.7 \\
+0.4\end{array}$ \\
\hline A. veronii AS-228 & $\mathrm{O}: 23$ & $\begin{array}{l}+ \\
+ \\
-\end{array}$ & $\begin{array}{l}- \\
- \\
+\end{array}$ & $\begin{array}{l}- \\
+ \\
+\end{array}$ & $\begin{array}{l}+1.3 \\
-0.2 \\
+0.9\end{array}$ \\
\hline
\end{tabular}

* Exposure to $65 \%$ pooled human serum.

† Exposure to $65 \%$ pooled human serum (complement-inactivated).

$\ddagger$ Addition of polymyxin B nonapeptide $\left(30 \mu \mathrm{g} \mathrm{ml}^{-1}\right)$.

$\int$ Change in viable progeny $\left(\log _{10}\right.$ c.f.u.) at $120 \mathrm{~min}$. 
Table 4. Effect of multiple cycles of PHS on the susceptibility of Aeromonas to complement-mediated lysis

\begin{tabular}{|lcccc|}
\hline Organism & Serogroup & $\begin{array}{c}\text { Challenge } \\
\text { inoculum }\end{array}$ & $\begin{array}{c}\text { Percentage } \\
\text { survival }\end{array}$ \\
\cline { 4 - 5 } & & & Cycle 1 Cycle 2 \\
\hline $\begin{array}{l}\text { A. bydrophila } \\
\text { AH-78 }\end{array}$ & $\mathrm{O}: 22$ & $1.2 \times 10^{7}$ & 1 & 0 \\
A. veronii AS-178 & $\mathrm{O}: 36$ & $1.7 \times 10^{7}$ & 22 & 100 \\
A. bydropbila & $\mathrm{O}: 11$ & $2.1 \times 10^{6}$ & 48 & 31 \\
AH-121 & & & & \\
Clone 1* & & $8.4 \times 10^{6}$ & 2 & NT \\
Clone 3* & & $3.7 \times 10^{6}$ & 1 & NT \\
Clone 4* & & $5.3 \times 10^{6}$ & 6 & NT \\
Clone 6* & & $9.8 \times 10^{7}$ & 100 & NT \\
\hline
\end{tabular}

NT, Not tested.

* Clone 1 was derived from the parental strain AH-121 and had never been exposed to serum; clones 3 and 4 were recovered as viable progeny after exposure of AH-121 to PHS for $120 \mathrm{~min}$; clone 6 was recovered after 240 min exposure (two cycles) to PHS.

\section{Clonal susceptibility}

We next investigated the one strain of serogroup O:11 that had previously been determined to be susceptible to complement-mediated lysis. Strain AH-121 was exposed to multiple cycles of fresh $65 \%$ PHS and the percentage viable progeny (compared to $t=0$ ) were measured and compared to a serum-susceptible strain (AH-78) and a serum-resistant isolate ( $A$. veronii AS-178). As can be seen in Table 4 , no viable progeny could be detected for strain AH-78 after two cycles of $65 \%$ PHS. In contrast, for strain AS-178 a significant decrease $(78 \%)$ was noted after one cycle; however, the remaining viable bacteria when subjected to another round of exposure to PHS rapidly multiplied to yield c.f.u. slightly exceeding the initial inoculum. For strain AH-121, successive cycles of ex- posure to $65 \%$ PHS resulted in continued decreases in c.f.u., although the results of a second cycle of exposure to PHS were not as dramatic as those obtained from the first challenge. Clones of strain AH-121 recovered from successive cycles of PHS exposure showed major differences in susceptibility to complement-mediated lysis. Clone 121-6 recovered from a second cycle exposure of parental strain AH-121 to PHS (at $240 \mathrm{~min}$ ) was completely refractory to PHS upon rechallenge with PHS. This was dramatically different from results obtained with clones 121-3 and 121-4, which were recovered from single-cycle exposure to PHS.

\section{Correlation of virulence properties with serum susceptibility}

Finally we studied six strains (three serum-resistant, three serum-susceptible) in regard to their activation of complement, LPS chemotype, and pathogenicity in mice (Table 5). All six strains were able to activate complement (94-100\%) based upon complement depletion assays regardless of their susceptibility to complement-mediated lysis; five of these six strains also bound $\mathrm{C} 3 \mathrm{~b}$ to their cell surface. The only exception was $A$. bydrophila LL1, an isolate originally recovered from a moribund fish, that has previously been demonstrated by immunoblotting to contain an $\mathrm{S}$ layer antigenically distinct from those of most other S-layer-positive $A$. bydrophila strains (Kokka et al., 1992). With regard to LPS chemotypes and mouse pathogenicity, differences were found that appear to be directly related to serum susceptibility status. All three serum-resistant strains were found to be moderately pathogenic for mice and to have a defined LPS pattern of either the A or B chemotype. In contrast, all three serumsusceptible strains were of low pathogenicity and did not exhibit a detectable $O$ polysaccharide side chain profile upon silver staining (type C pattern).

\section{DISCUSSION}

The bacteriolytic activity of human serum is one of several natural host defence mechanisms that are active against Gram-negative bacterial pathogens. This activity

Table 5. Correlation of serum susceptibility with various structural and pathogenic properties

\begin{tabular}{|lccccc|}
\hline Strain & $\begin{array}{c}\text { Serum } \\
\text { susceptibility }\end{array}$ & $\begin{array}{c}\text { Complement } \\
\text { activation } \\
\mathbf{( \% )}\end{array}$ & $\begin{array}{c}\text { C3b } \\
\text { binding }\end{array}$ & $\begin{array}{c}\text { LPS } \\
\text { type* }\end{array}$ & LD-50† \\
\hline LL1 (O:11) & $+0 \cdot 9$ & 100 & - & A & $7 \cdot 2$ \\
AS-28 (O:11) & $+1 \cdot 1$ & 97 & + & A & $7 \cdot 2$ \\
NMRI-7 (O:34) & $+1 \cdot 0$ & 100 & + & B & $7 \cdot 6$ \\
AH-78 (O:22) & $-5 \cdot 0$ & 100 & + & C & $8 \cdot 3$ \\
ATCC 14715 (O:22) & $-4 \cdot 5$ & 94 & + & C & $8 \cdot 5$ \\
AS-53 (R) & $-5 \cdot 0$ & 100 & + & C & $8 \cdot 4$ \\
\hline
\end{tabular}

* LPS types: type A, homogeneous side chain profile; type B, heterogeneous side chain profile; type C, side-chain deficient.

f $\log _{10} 50 \%$ lethal dose (Swiss Webster mice). 
is largely dependent upon complement-mediated lysis or killing of intact bacteria, and individuals that are deficient in one or more complement components, most notably $\mathrm{C} 3$ and $\mathrm{C} 5$, are at increased risk of developing serious lifethreatening infections caused by Neisseria meningitidis, Streptococcus pneumoniae and Haemophilus influenzae (Lachmann, 1990; Figueroa \& Densen, 1991). In individuals with alcoholic or non-alcoholic cirrhosis, diminished bactericidal and opsonic activity has been noted (Akalin et al., 1985). Underlying liver disease, particularly Laennec's cirrhosis, is a well-recognized predisposing condition leading to invasive disease caused by the genus Aeromonas (Janda \& Duffey, 1988).

Earlier studies have established that both $A$. bydropbila and $A$. veronii biotype sobria (formerly referred to as $A$. sobria) are inherently more resistant to complementmediated lysis by fresh serum than is $A$. caviae (Janda $e t$ al., 1984; Brenden \& Janda, 1986; Massad et al., 1991). This difference in susceptibility appears to correlate in vivo with the greater propensity of the former two species to cause serious invasive infections including septicaemia (Janda et al., 1994). Recently we identified a group of highly invasive strains of $A$. bydrophila and $A$. veronii that are characterized by a number of unique phenotypic and structural properties including possession of an $\mathrm{S}$ layer (Kokka et al., 1991a). Previous studies by Munn et al. (1982) on S-layer-positive $A$. salmonicida indicated that resistance to the bactericidal activity of fresh serum was partly attributable to this layer. We therefore set out to compare the susceptibility properties of a group of these $0: 11$ strains to those of a control group which were $S$ layer-negative and belonged to serogroups other than $\mathrm{O}: 11$.

The results in Fig. 1 indicate that there is a significant difference in these two groups in regard to their ability to resist the normal lytic action of complement. Overall, $\mathrm{O}: 11$ S-layer-positive strains were significantly more resistant to PHS than non-O:11 strains. Within the non$\mathrm{O}: 11$ group, however, two distinct populations could be discerned. The larger of these two groups was also refractory to complement-mediated lysis despite the fact that the strains were S-layer-negative; selected strains analysed by SDS-PAGE and stained for O polysaccharide side chains by silver straining were shown to have an intact LPS side chain profile. In contrast, the slightly smaller group was extremely susceptible to complementmediated lysis, showing kinetics of inactivation similar to rough mutants of the Ra or Rc chemotypes of E. coli or $S$. typhimurium (Hitchcock et al., 1986). These strains had a somatic antigen definable by serogrouping. Upon LPS analysis, no side chain activity was detectable. This resuit may indicate that the total amount of polysaccharide side chains present is either diminished or of a truncated form, which would explain both results. Regardless of which alternative is correct, these strains were less pathogenic in mice and acted like attenuated or non-virulent isolates (Janda \& Kokka, 1991).

For $\mathrm{O}: 11$ strains, all isolates tested (with one exception) were serum-resistant under the defined conditions. The serum-susceptible strain was found, upon agar cloning, to be comprised of both serum-susceptible and serumresistant progeny, with the former predominating in unselected populations. When continuously challenged with successive cycles of PHS, the serum-resistant clones predominated suggesting that a similar situation would occur in vivo. This contrasts sharply with non-O:11 serumsusceptible isolates, where complete elimination of infectious progeny was apparent within two cycles of PHS incubation. For $\mathrm{O}: 11$ strains, susceptibility to complement-mediated lysis could not be enhanced with somatic or whole-cell antibodies nor (with one exception) in the presence of PMBN, a peptide known to enhance the lytic activity of complement for many Gram-negative bacteria at a concentration of $30 \mu \mathrm{g} \mathrm{ml}^{-1}$ (Viljanen et al., 1986). The inability of these strains to be lysed by complement was not due to failure to activate complement or bind C3b to the cell surface. Rather, it appears that the failure to be lysed by fresh pooled serum is due to a defect in the activation of the terminal components of the complement pathway.

The results suggest that S-layer-containing aeromonads are inherently resistant to complement-mediated lysis. This effect is probably not directly due to the presence of the $S$ layer for the following reasons: (1) many non-O:11 strains that are S-layer-negative are serum-resistant; (2) serum-susceptibility of strains generally correlated with the absence of detectable LPS side chains as determined by silver staining of SDS-polyacrylamide gels of proteinase-K-treated whole-cell extracts; and (3) a previously analysed spontaneous mutant of an O:11 strain that was autoagglutination- and S-layer-negative was still resistant to the lytic activity of fresh serum, presumably by maintenance of an intact homogeneous $\mathrm{O}$ polysaccharide side chain profile (Kokka et al., 1991b). The fact that strain AS-28 was lysed by PHS in the presence of PMBN and that strain LL1 failed to bind C3b to the cell surface implies some heterogeneity in regard to physiological and biological functions. Support for this concept stems from recent molecular investigations which have demonstrated extensive amino acid sequence variation in the N-termini of a large number of SAPs (Kostrzynska $e t$ al., 1992). Previous studies with the $\mathrm{S}$ layer of $A$. salmonicida (formerly referred to as the A layer) indicate that the paracrystalline surface layer of this psychrophilic species appears to have many more functions associated with virulence than do the SAPs of $A$. bydrophila and $A$. veronii biotype sobria. Some of these proposed functions for the $\mathrm{S}$ layer of $A$. salmonicida include a role in iron transport, binding of $\operatorname{IgG}$ and $\mathrm{IgM}$ from serum, providing entry into phagocytic cells, a protective barrier against the harmful effects of proteases and complement, and the binding of high molecular mass basement membrane molecules such as laminin, fibronectin and collagen (Kay \& Trust, 1991). Although the S layer of $A$. bydrophila and $A$. veronii does not at present appear to have such a major role in pathogenesis as demonstrated for $A$. salmonicida (e.g. anti-lytic properties) it may well be that the $\mathrm{S}$ layer possesses anti-phagocytic activity which may aid in its systemic dissemination once invasion through the gas- 
trointestinal mucosa has occurred. A recent study from our laboratory, demonstrating enhanced virulence of Slayer-negative strains in mice upon intraperitoneal injection when mixed with purified S layer, suggests that this is a distinct possibility (Kokka et al., 1992). Further studies on the opsonic and phagocytic activity of professional and non-professional phagocytes with $\mathrm{O}: 11$ strains await the construction of isogenic mutants lacking a paracrystalline surface array.

\section{REFERENCES}

Abbott, S. L., Cheung, W. K., Kroske-Bystrom, S., Malekzadeh, T. \& Janda, J. M. (1992). Identification of Aeromonas strains to genospecies level in the clinical laboratory. J Clin Microbiol 30, 1262-1266.

Aguero, M. E., Aron, L., Deluca, A. G., Timmis, K. N. \& Cabello, F. C. (1984). A plasmid-encoded outer membrane protein, $\operatorname{TraT}$, enhances resistance of Escherichia coli to phagocytosis. Infect Immun 46, 740-746.

Akalin, H. E., Laleli, Y. \& Telafar, H. (1985). Serum bactericidal and opsonic activities in patients with non-alcoholic cirrhosis. $Q \mathrm{~J} \mathrm{Med}$ 56, 431-437.

Blaser, M. J., Smith, P. F., Hopkins, J. A., Heinzer, I., Bryner, J. H. \& Wang, W.-L. L. (1987). Pathogenesis of Campylobacter fetus infections: serum resistance associated with high-molecular-weight surface proteins. J Infect Dis 155, 696-706.

Brenden, R. A. \& Janda, J. M. (1986). The interaction of complement components with Aeromonas species. Can J Microbiol 32, 1-3.

Figueroa, J. E. \& Densen, P. (1991). Infectious diseases associated with complement deficiencies. Clin Microbiol Rev 4, 359-395.

Hitchcock, P. J., Leive, L., Makela, P. H., Rietschel, E. T., Strittmatter, W. \& Morrison, D. C. (1986). Lipopolysaccharide nomenclature - past, present, and future. J Bacteriol 166, 699-705.

Horwitz, M. A. \& Silverstein, S. C. (1980). Influence of Escherichia coli capsule on complement fixation and on phagocytosis and killing by human phagocytes. $J$ Clin Invest 65, 82-94.

Janda, J. M. \& Duffey, P. S. (1988). Mesophilic aeromonads in human disease: current taxonomy, laboratory identification, and infectious disease spectrum. Rev Infect Dis 10, 980-997.

Janda, J. M. \& Kokka, R. P. (1991). The pathogenicity of Aeromonas strains relative to genospecies and phenospecies identification. FEMS Microbiol Lett 90, 29-34.

Janda, J. M., Brenden, R. \& Bottone, E. J. (1984). Differential susceptibility to human serum by Aeromonas spp. Curr Microbiol 11, 325-328.

Janda, J. M., Guthertz, L. S., Kokka, R. P. \& Shimada, T. (1994). Laboratory characteristics and clinical observations on the role of Aeromonas species in septicemia. Clin Infect Dis 19, 77--83.

Kay, W. W. \& Trust, T. J. (1991). Form and functions of the regular surface array (S-layer) of Aeromonas salmonicida. Experientia 47, $412-414$.
Kobayashi, Y., Ohta, H., Kokeguchi, S., Murayama, Y., Kato, K., Kurihara, H. \& Fukui, K. (1993). Antigenic properties of Campylobacter rectus (Wolinella recta) major S-layer proteins. FEMS Microbiol Lett 108, 275--280.

Kokka, R. P. \& Janda, J. M. (1990). Isolation and identification of autoagglutinating serogroup O:11 Aeromonas strains in the clinical laboratory. J Clin Microbiol 28, 1297-1299.

Kokka, R. P., Vedros, N. A. \& Janda, J. M. (1990). Electrophoretic analysis of the surface components of autoagglutinating surface array protein-positive and surface array protein-negative Aeromonas bydropbila and Aeromonas sobria. J Clin Microbiol 28, 2240-2247.

Kokka, R. P., Janda, J. M., Oshiro, L. S., Altwegg, M., Shimada, T., Sakazaki, R. \& Brenner, D. J. (1991a). Biochemical and genetic characterization of autoagglutinating phenotypes of Aeromonas species associated with invasive and noninvasive disease. J Infect Dis 163, 890-894.

Kokka, R. P., Vedros, N. A. \& Janda, J. M. (1991b). Characterization of classic and atypical serogroup O:11 Aeromonas: evidence that the surface array protein is not directly involved in mouse pathogenicity. Microb Patbog 10, 71-79.

Kokka, R. P., Vedros, N. A. \& Janda, J. M. (1992). Immunochemical analysis and possible biological role of an Aeromonas bydrophila surface array protein in septicaemia. J Gen Microbiol 138, 1229-1236.

Kostrzynska, M., Dooley, J. S. G., Shimojo, T., Sakata, T. \& Trust, T. J. (1992). Antigenic diversity of the S-layer proteins from pathogenic strains of Aeromonas bydrophila and Aeromonas veronii biotype sobria. J Bacteriol 174, 40-47.

Lachmann, P. J. (1990). Complement genetics and host defense. Zentralbl Bakteriol 274, 316-324.

Massad, G., Arceneaux, J. E. L. \& Byers, B. R. (1991). Acquisition of iron from host sources by mesophilic Aeromonas species. J Gen Microbiol 137, 237-241.

Messner, P. \& Sleytr, U. B. (1992). Crystalline bacterial cell-surface layers. Adv Microb Physiol 33, 213-275.

Munn, C. B., Ishiguro, E. E., Kay, W. W. \& Trust, T. J. (1982). Role of surface components in serum resistance of virulent Aeromonas salmonicida. Infect Immun 36, 1069-1075.

Paula, S. J., Duffey, P. S., Abbott, S. L., Kokka, R. P., Oshiro, L. S., Janda, J. M., Shimada, T. \& Sakazaki, R. (1988). Surface properties of autoagglutinating mesophilic aeromonads. Infect Immun 56, 2658-2665.

Reed, L. J. \& Muench, H. (1938). A simple method of estimating fifty percent endpoints. Am J Hyg 27, 493-497.

Tamplin, M. L., Specter, S., Rodrick, G. E. \& Friedman, H. (1983). Differential complement activation and susceptibility to human bactericidal action by Vibrio species. Infect Immun 42, 1187-1190.

Taylor, P. W. (1983). Bactericidal and bacteriolytic activity of serum against Gram-negative bacteria. Microbiol Rev 47, 46-83.

Viljanen, P., Kayhty, H. \& Vaara, T. (1986). Susceptibility of Gramnegative bacteria to the syngergistic bactericidal action of serum and polymyxin B nonapeptide. Can J Microbiol 32, 66-69.

Received 14 February 1994; revised 12 April 1994; accepted 26 May 1994. 